\title{
PENGETAHUAN, SIKAP, DAN DUKUNGAN KELUARGA DENGAN MINAT IMUNISASI MEASLES RUBELLA DI KELURAHAN BUKIT WOLIO INDAH KOTA BAUBAU
}

\author{
Taswin ${ }^{凶}$, Waode Azfari Azis, Wahyuddin, Dahmar, Erni, Ni’ma Meilani \\ Fakultas Kesehatan Masyarakat, Universitas Dayanu Ikhsanuddin Baubau
}

\section{ARTICLE INFO}

Article history

Submitted : 2020-07-22

Revised : 2020-07-25

Accepted : 2020-08-07

\section{Keywords:}

Attitude

Family Support

Knowledge

MR Immunization

\section{Kata Kunci:}

Sikap

Dukungan Keluarga

Pengetahuan

Imunisasi MR

\begin{abstract}
Measles, or known in Indonesian as measles, and Rubella, are two infectious diseases that are contagious. Data for 2018 MR immunization coverage until the end of november only reaches $(73.7 \%)$ and Measles Immunization trends tend to fluctuate in Bukit Wolio Indah Kelurahan. This happens because of various factors namely mother's knowledge, attitudes, and family support which have been formulated as the reason of the many factors. This study aims to determine how the relationship of knowledge, attitudes, and family support to the interest of MR immunization in the Bukit Wolio Indah Village, Baubau City. This type of research is analytical survey with cross sectional approach, and uses simple random sampling technique. The number of samples in the study were 70 respondents. The analysis used was univariate and bivariate analysis at $95 \%$ confidence level $(\alpha=0.05)$. Chi square test results obtained from the study that knowledge of MR immunization interests $(\rho=0.005)$, attitudes with MR immunization interests $(\rho=0.004)$, and family support with MR immunization interests $(\rho=0.273)$. The conclusion from this study there is no relationship on the family support variable, and there is a relationship on the attitude and knowledge variables with the interest of MR immunization in Bukit Wolio Indah Village, Baubau City. Suggestions that health practitioners can better socialize to the public about the benefits of MR immunization.

Measles, atau yang dikenal dalam Bahasa Indonesia campak, dan Rubella, merupakan dua penyakit infeksi yang menular. Puskesmas bukit wolio indah memiliki cakupan imunisasi MR sampai akhir November 2018 mencapai (73,7\%) dan tren Imunisasi campak cenderung naik turun di Kelurahan Bukit Wolio Indah. Hal ini terjadi karena adanya berbagai faktor yaitu pengetahuan ibu, sikap, dan dukungan keluarga telah dirumuskan sebagai alasan dari sekian banyak faktor. Tujuan penelitian mengetahui hubungan antara pengetahuan, sikap, dan dukungan keluarga terhadap minat imunisasi MR. Jenis Penelitian yang digunakan bersifat survei analitik dengan pendekatan cross sectional, dan menggunakan teknik pengambilan sampel simple random sampling. Jumlah sampel dalam penelitian sebanyak 70 responden. Analisis yang digunakan adalah analisis univariat dan bivariat pada taraf kepercayaan 95\% $(\alpha=0,05)$. Hasil uji chi square yang diperoleh dari penelitian bahwa pengetahuan dengan minat imunisasi MR $(\rho=0,005)$, sikap dengan minat imunisasi MR $(\rho=0,004)$, dan dukungan keluarga dengan minat imunisasi MR $(\rho=0,273)$. Kesimpulan dari penelitian ini tidak terdapat hubungan pada variabel dukungan keluarga, serta terdapat hubungan pada variabel sikap dan pengetahuan dengan minat imunisasi MR di Kelurahan Bukit Wolio Indah Kota Baubau. Saran agar praktisi kesehatan dapat lebih mensosialisasikan kepada masyarakat tentang manfaat imunisasi MR.
\end{abstract}

\section{Corresponding Author:}

Taswin

Fakultas Ilmu Kesehatan Masyarakat, Universitas Dayanu Ikhsanuddin Baubau

Telp. 085255588811

Email: taswin@unidayan.ac.id

\section{PENDAHULUAN}

Measles, atau yang dikenal dalam Bahasa Indonesia campak Jerman, merupakan dua penyakit infeksi yang sangat menular. Sama seperti penyakit yang disebabkan oleh virus pada umumnya, kedua penyakit ini tidak memiliki pengobatan, tetapi dapat dicegah dengan imunisasi. Penyakit Measles dan Rubella (MR) merupakan penyakit yang kembali muncul dan menjadi perhatian dunia. Campak merupakan penyakit yang sangat mudah menular karena disebabkan oleh virus 
yang ditularkan melalui batuk dan bersin. Rubella adalah penyakit yang juga disebabkan oleh virus yang muncul dengan ditandai demam ringan dan bahkan penyakit ini muncul tanpa gejala. Penyakit ini sangat rentan menginfeksi anak pada usia 9 bulan sampai 15 tahun. (Kemenkes RI, 2017)

World Health Organization (WHO) memiliki 6 daerah intervensi, yaitu: Africa (AFR); Eastern Mediterranean (EMR); Europe (EUR); South East Asia (SEAR); Western Pacific (WPR) yang memiliki angka kejadian MR yang berbeda-beda dan dibagi berdasarkan pada rate Campak <5 kasus per 1.000.000 penduduk disetiap daerah intervensinya. SEAR merupakan daerah intervensi WHO yang menduduki posisi ke-3 terbesar sebelum WPR (6 per 1.000.000 penduduk) \& AFR (4 per 1.000 .000 penduduk. (American Red Cross CDC; UNICEF; UNF \& WHO, 2017)

Indonesia menjadi salah satu dari 11 negara anggota SEAR yang menduduki posisi ke-3 tertinggi dengan rate kejadian campak antara 10 sampai 50 kasus atau dengan persentase insiden campak sebesar $18 \%$ sebelum Bangladesh dengan rate antara $10-50$ kasus dan India dengan rate sebesar 10 - 50 kasus. (American Red Cross CDC; UNICEF; UNF \& WHO, 2017)

Pada tahun 2017, Indonesia mengadakan kampanye pemberantasan virus measles dan pengontrolan virus rubella dengan mengadakan imunisasi fase I pada tahun 2017 di Pulau Jawa, dan fase II pada tahun 2018 di luar Pulau Jawa. Namun, insiden kedua penyakit masih tinggi, dan walaupun telah melebihi target fase I, imunisasi masih menuai banyak kontra, sehingga pemerintah melaksanakan kampanye vaksinasi MR. Vaksin MR (Measles Rubella) memberikan manfaat seperti dapat melindungi anak dari kecacatan dan kematian akibat komplikasi pneumonia, diare, kerusakan otak, ketulian, kebutaan dan penyakit jantung bawaan. (Ditjen P2P. K. R, 2016)

Data survailans penyakit campak dan rubella selama lima tahun terakhir menunjukan $70 \%$ kasus rubella terjadi pada kelompok usia $\geq 15$. Terdapat 83 kasus pasti Congenital Rubella Syndrome (CRS) pada tahun 2015 2016 diantaranya $77 \%$ menderita kelainan jantung, 67,5\% menderita katarak dan $47 \%$ menderita ketulian. (Ditjen P2P. K. R, 2016)
Insiden campak di Indonesia pada tahun 2016 adalah sebesar 2,7 per 100.000 penduduk dengan jumlah kasus sebanyak 6.880 kasus. (Kemenkes RI, 2017). Berdasarkan pada target Renstra Kementerian Kesehatan tahun 2017, persentase desa UCI Sulawesi Tenggara belum mencapai target dimaksud karena baru mencapai $85,92 \%$, lebih tinggi dari capaian tahun 2016 sebesar 82,87\%. (Tenggara, 2018). Berdasarkan data dari Dinas Kesehatan Kota Baubau tahun 2018 cakupan imunisasi Measles Rubella (MR) untuk wilayah Kota Baubau mencapai 47.182 jiwa $(95.60 \%)$ ). (Dinas Kesehatan Kota Baubau, 2019)

Cakupan Imunisasi campak di Puskesmas Bukit Wolio Indah Kelurahan Bukit Wolio Indah sebagai berikut tahun 2016 sebanyak 102 Bayi yang mendapatkan imunisasi campak dari total 211 Bayi, Tahun 2017 sebanyak 186 bayi yang mendapatkan imunisasi campak dari total 215 Bayi, dan Tahun 2018 sebanyak 131 Bayi yang mendapatkan imunisasi campak dari total 221 Bayi. Tren Imunisasi campak cenderung naik turun. Hal ini terjadi karena adanya berbagai faktor yaitu pengetahuan ibu, sikap akan imunisasi, dan dukungan keluarga telah dirumuskan sebagai alasan dari sekian banyak factor. (Puskesmas Bukit Wolio Indah, 2019)

Puskesmas Bukit Wolio Indah memiliki jumlah target imunisasi MR sebesar 4176 jiwa meliputi anak usia 9 bulan sampai 15 tahun. Target ini belum terpenuhi sampai akhir November 2018, cakupan hanya mencapai 3078 jiwa $(73,7 \%)$ (Arman, 2019). Isu yang muncul terkait cakupan yang belum mencapai target ini terkait tentang manfaat, kehalalan vaksin, dan efek lanjutan setelah vaksin. Tujuan penelitian mengetahui hubungan pengetahuan, sikap, dam dukungan keluarga dengan minat imunisasi Measles Rubella di Kelurahan Bukit Wolio Indah Kota Baubau.

\section{METODE PENELITIAN Jenis Penelitian}

Jenis Penelitian yang digunakan bersifat survei analitik dengan pendekatan cross sectional.

\section{Lokasi Penelitian}

Penelitian ini dilakukan di Kelurahan Bukit Wolio Indah Kota Baubau pada bulan September sampai Oktober tahun 2019. 


\section{Populasi dan Sampel}

Jumlah populasi sebanyak 219 dan sampel sebanyak 70 responden diperoleh dengan menggunakan menggunakan rumus sebagai berikut:

Isaac dan Michel:

$$
S=\frac{\lambda^{2} \cdot \mathbf{N} \cdot \mathbf{P} \cdot \mathbf{Q}}{\mathbf{d}^{2}(\mathbf{N}-1)+\lambda^{2} \cdot \mathbf{P} \cdot \mathbf{Q}}
$$

\section{Keterangan:}

$$
\begin{array}{ll}
\mathrm{S} & =\text { Jumlah Sampel } \\
\mathrm{N} & =\text { Jumlah Populasi } \\
\lambda^{2} & =1 \\
\mathrm{~d} & =\text { Tingkat kepercayaan/ketepatan } \\
& \quad \text { yang digunakan }(\mathrm{d}=0,05) \\
\mathrm{P}: \mathrm{Q} & =0,5
\end{array}
$$

Sehingga jumlah sampel yang digunakan dalam penelitian ini adalah sebagai berikut:

$$
\begin{aligned}
\mathrm{S} & =\frac{\lambda^{2} \cdot \mathrm{N} \cdot \mathrm{P} \cdot \mathrm{Q}}{\mathrm{d}^{2}(\mathrm{~N}-1)+\lambda^{2} \cdot \mathrm{P} \cdot \mathrm{Q}} \\
& =\frac{1^{2} \cdot 219 \cdot 0,5 \cdot 0,5}{0,05(219-1)+1^{2} \cdot 0,5 \cdot 0,5} \\
& =\frac{219 \times 0,25}{0,0025(218)+0,25} \\
& =\frac{54,75}{0,545+0,25} \\
& =\frac{54,75}{0,795} \\
& =70 \text { orang tua }
\end{aligned}
$$

Jumlah sampel sebesar 70 orang tua. Metode sampling yang digunakan simple random sampling atau pengambilan sampel secara acak sederhana adalah pengambilan anggota sampel random dari populasi yang ditarik secara lot tanpa memperhatikan strata yang ada dalam populasi itu. Dimana dilakukan lot sebanyak 70 kali dari total 219 populasi.

\section{Pengumpulan Data}

Jenis dan teknik pengumpulan data yang digunakan dalam penelitian ini adalah data primer yang diperoleh langsung dari responden dengan kuesioner dan data sekunder diperoleh dari profil Puskesmas Bukit Wolio Indah Kecamatan Wolio Kota Baubau.

\section{Pengolahan dan Penyajian Data}

Teknik pengolahan data dilakukan dengan menggunakan komputer program softwere Statistical Package for Social Science (SPSS). Data yang diolah kemudian disajikan dalam bentuk tabel distribusi frekuensi berdasarkan variabel yang diteliti, selanjutnya dinarasikan.

\section{Analisis Data}

Analisis yang digunakan adalah analisis univariat dan bivariat pada taraf kepercayaan 95\% $(\alpha=0,05)$.

\section{HASIL PENELITIAN}

Berdasarkan hasil pengolahan data yang telah dilakukan, maka disajikan hasil penelitian sebagai berikut :

Tabel 1. Distribusi Responden berdasarkan Karakteristik Responden di Kelurahan Bukit Wolio Indah Kota Baubau

\begin{tabular}{lcc}
\hline $\begin{array}{l}\text { Karakteristik } \\
\text { Responden }\end{array}$ & n & \% \\
\hline Pendidikan & & \\
SD & 4 & 5,7 \\
SMP & 8 & 11,4 \\
SMA & 41 & 58,6 \\
Akademi & 17 & 24,3 \\
\hline Umur Orang Tua & & \\
20 - 25 Tahun & 19 & 27,1 \\
26-30 Tahun & 27 & 38,6 \\
31-35 Tahun & 13 & 18,6 \\
36-40 Tahun & 11 & 15,7 \\
\hline Agama & & \\
Islam & 70 & 100 \\
\hline Alamat & & \\
Wurahabake & 22 & 31,4 \\
Medibrata & 10 & 14,3 \\
Lamanaga Dalam & 12 & 17,1 \\
Lamanaga Luar & 13 & 18,6 \\
Gatot Subroto & 13 & 18,6 \\
\hline Usia Bayi & & \\
2-3 Bulan & 2 & 2,9 \\
4 - 5 Bulan & 11 & 15,7 \\
6-7 Bulan & 13 & 18,6 \\
8 - 9 Bulan & 21 & 30,0 \\
10 - 11 Bulan & 23 & 32,9 \\
\hline Data primer, 2019 & & \\
\hline
\end{tabular}

Berdasarkan tabel 1 diperoleh hasil penelitian tentang karakteristik responden menunjukan bahwa dari 70 responden, yang 
berpendidikan paling banyak adalah SMA dengan jumlah $(58,6 \%)$ dan yang paling sedikit adalah SD dengan jumlah (5,7\%). Sedangkan umur orang tua menunjukan dari 70 responden paling banyak berada pada kelompok umur 26 30 tahun dengan jumlah $(38,6 \%)$ dan paling sedikit adalah kelompok umur 36 - 40 tahun dengan jumlah $(15,7 \%)$.

Kemudian agama dari 70 responden menunjukkan bahwa seluruh responden $(100 \%)$ beragama islam. Sedangkan Alamat menunjukan bahwa dari 70 responden alamat paling banyak berada pada wurahabake dengan jumlah (31,4\%), dan alamat paling sedikit adalah medibrata dengan jumlah $(14,3)$, Dan usia bayi menunjukkan dari 70 responden yang paling banyak memiliki usia bayi $10-11$ bulan dengan jumlah $(32,9 \%)$ dan paling sedikit usia bayi $2-3$ bulan dengan jumlah $(2,9 \%)$.

Tabel 2 berdasarkan variabel penelitian menunjukkan hasil penelitian sebagai berikut bahwa dari 70 responden (100\%), diperoleh pengetahuan paling banyak baik dengan jumlah $40(57,1 \%)$ responden, dan paling sedikit pengetahuan kurang baik dengan jumlah 30 $(42,9 \%)$ responnden. Sikap responden paling banyak, yaitu sikap positif terhadap imunisasi Measles Rubella (MR) dengan jumlah 60 $(85,7 \%)$ responden, dan paling sedikit sikap Negatif dengan jumlah $10(14,3 \%)$ responden.
Dukungan keluarga responden yang paling banyak adalah tidak didukung oleh keluarga dengan jumlah $43(61,4 \%)$ responden dan yang paling sedikit adalah didukung dengan jumlah $27(38,6 \%)$ responden. Minat imunisasi measles rubella paling banyak yaitu yang tidak minat imunisasi Measles Rubella 37 (52,9\%) responden dan yang sedikit adalah yang berminat imunisasi Measles Rubella $33(47,1 \%)$ responden.

Tabel 2. Distribusi Responden berdasarkan Variabel Penelitian di Kelurahan Bukit Wolio Indah Kota Baubau

\begin{tabular}{lll}
\hline Varibel Penelitian & n & \% \\
\hline Pengetahuan & & \\
$\quad$ Kurang Baik & 30 & 42,9 \\
Baik & 40 & 57,1 \\
\hline Sikap & & \\
$\quad$ Negatif & 10 & 14,3 \\
$\quad$ Positif & 60 & 85,7 \\
\hline Dukungan Keluarga & & \\
$\quad$ Tidak Didukung & 43 & 61,4 \\
$\quad$ Didukung & 27 & 38,6 \\
\hline Minat Imunisasi & & \\
Rubella & & \\
$\quad$ Tidak Minat & 33 & 47,1 \\
$\quad$ Minat & 37 & 52,9 \\
\hline Data primer, 2019 & &
\end{tabular}

Tabel 3. Analisis Hubungan Pengetahuan, Skap, dan Dukungan Keluarga dengan Minat Imunisasi Measles Rubella (MR) di Kelurahan Bukit Wolio Indah Kota Baubau

\begin{tabular}{|c|c|c|c|c|c|c|c|}
\hline \multirow{3}{*}{ Variabel Penelitian } & \multicolumn{4}{|c|}{ Minat Imunisasi MR } & \multirow{2}{*}{\multicolumn{2}{|c|}{ Total }} & \multirow{3}{*}{$P$ Value } \\
\hline & \multicolumn{2}{|c|}{ Minat } & \multicolumn{2}{|c|}{ Tidak Minat } & & & \\
\hline & $\bar{n}$ & $\%$ & $\mathbf{n}$ & $\%$ & $\mathbf{N}$ & $\%$ & \\
\hline \multicolumn{8}{|l|}{ Pengetahuan } \\
\hline Kurang Baik & 15 & 21,4 & 15 & 21,4 & 30 & 100,0 & \multirow{3}{*}{0,005} \\
\hline Baik & 18 & 25,7 & 22 & 31,4 & 40 & 100,0 & \\
\hline Total & 33 & 47,1 & 37 & 52,9 & 70 & 100,0 & \\
\hline \multicolumn{8}{|l|}{ Sikap } \\
\hline Negatif & 9 & 12,9 & 1 & 1,4 & 10 & 100,0 & \multirow{3}{*}{0,004} \\
\hline Positif & 24 & 34,3 & 36 & 51,4 & 60 & 100,0 & \\
\hline Total & 33 & 47,1 & 37 & 52,9 & 70 & 100,0 & \\
\hline \multicolumn{8}{|l|}{ Dukungan Keluarga } \\
\hline Tidak didukung & 23 & 32,9 & 20 & 28,6 & 43 & 100,0 & \multirow{3}{*}{0,273} \\
\hline Didukung & 10 & 14,3 & 17 & 24,3 & 27 & 100,0 & \\
\hline Total & 33 & 47,1 & 37 & 52,9 & 70 & 100,0 & \\
\hline
\end{tabular}


Tabel 3, di atas menunjukkan bahwa pada variabel pengetahuan dari 40 responden yang memiliki pengetahuan baik, terdapat 18 $(25,7 \%)$ yang minat, dan $22(31,4 \%)$ yang tidak minat imunisasi Measles Rubella (MR). Dari 30 yang memiliki pengetahuan kurang baik terdapat $15(21,4 \%)$ yang minat imunisasi Measles Rubella (MR) dan 15 (21,4\%) yang tidak minat. Hasil Uji statistik dengan menggunakan uji chis-quare pada tingkat kepercayaan $95 \%$ atau $\alpha=0,005$ didapatkan $\rho$ Value $>\alpha$ sehingga terdapat hubungan antara pengetahuan dengan minat imunisasi Measles Rubella (MR) di Kelurahan Bukit Wolio Indah Kota Baubau.

Variabel sikap menunjukkan bahwa dari 10 responden yang memiliki sikap negatif, terdapat $9(12,9 \%)$ yang minat imunisasi MR, dan $1(1,4 \%)$ yang tidak minat imunisasi Measles Rubella (MR). Dari 60 responden yang memiliki sikap positif $24(34,3 \%)$ yang minat imunisasi Measles Rubella (MR) dan 36 $(51,4 \%)$ yang tidak minat imunisasi Measles Rubella (MR). Hasil uji statistik pada tingkat kepercayaan $95 \%$ atau $\alpha=0,004$ didapatkan $\rho$ value $<\alpha$ sehingga terdapat hubungan antara sikap dengan minat imunisasi MR di Kelurahan Bukit Wolio Indah Kota Baubau.

$$
\text { Variabel dukungan keluarga }
$$

menunjukkan bahwa dari 43 responden yang tidak memiliki dukungan oleh keluarga terdapat 23 (32,9\%) yang minat imunisasi Measles Rubella (MR), dan $20(28,6 \%)$ yang tidak minat. Sedangkan dari 27 yang memiliki dukungan oleh keluarga terdapat $10(14,3 \%)$ yang minat imunisasi Measles Rubella (MR) dan $17(24,3 \%)$ yang tidak minat imunisasi Measles Rubella (MR). Hasil Uji statistik dengan menggunakan uji chis-quare pada tingkat kepercayaan $95 \%$ atau $\alpha=0,273$ didapatkan $\rho$ value $>\alpha$ sehingga $\mathrm{H}_{0}$ diterima, yang berarti bahwa tidak terdapat hubungan antara Dukungan keluarga dengan minat imunisasi Measles Rubella (MR) di Kelurahan Bukit Wolio Indah Kota Baubau.

\section{PEMBAHASAN}

Berdasarkan hasil pengolahan data yang telah dilakukan, maka disajikan hasil penelitian sebagai berikut:

\footnotetext{
Hubungan Antara Pengetahuan Orang Tua dengan Minat Imunisasi Measles Rubella (MR)
}

Hasil penelitian menunjukkan bahwa Hampir sebagian responden terdiri dari 40 $(57,1 \%)$ mempunyai pengetahuan baik tentang minat imunisasi Measles Rubella (MR). Dalam penelitian ini, Pengetahuan baik responden menggambarkan keyakinan responden tentang pengertian imunisasi Measles Rubella (MR), tujuan, manfaat, dan efek samping imunisasi Measles Rubella (MR), dimana dalam pengetahuan baik ini orang tua menyimpulkan bahwa mereka merasa imunisasi Measles Rubella (MR) mempunyai manfaat bagi bayi atau anak mereka.

Sebagian kecil 30 responden $(42,9 \%)$ memiliki pengetahuan kurang baik terhadap minat imunisasi Measles Rubella (MR). Pengetahuan mereka menyimpulkan bahwa imunisasi Measles Rubella (MR) itu tidak aman dan tidak penting untuk bayi.

Hasil penelitian juga menunjukkan bahwa responden yang mempunyai pengetahuan baik terdiri dari $40(57,1 \%)$ tetapi 22 responden $(31,4 \%)$ tidak minat imunisasi Measles Rubella (MR) pada bayinya karena jika melakukan imunisasi maka bayi mereka akan demam dan rewel, selain itu ibu juga sibuk dengan pekerjaan rumah sehingga tidak sempat membawa bayinya ke posyandu atau puskesmas. Sedangkan yang mempunyai pengetahuan baik dan terdapat 18 responden $(25,7 \%)$ minat imunisasi Measles Rubella (MR) pada bayinya karena ibu mengetahui manfaat dan bahaya dari tidak melakukan imunisasi Measles Rubella (MR) kepada bayi.

Pengetahuan ibu yang kurang baik 30 responden $(42,9 \%)$ dan terdapat 15 responden $(21,4 \%)$ minat imunisasi Measles Rubella (MR) hal ini terjadi karena mereka mengikuti anjuran dokter atau tenaga kesehatan, selanjutnya pengetahuan ibu yang kurang baik dan 15 respnden (21,4\%) tidak minat imunisasi Measles Rubella (MR) karena mereka merasa imunisasi Measles Rubella (MR) tidak ada manfaatnya bagi bayi mereka.

Hasil analisis disimpulkan bahwa pada variabel pengetahuan Hasil uji statistik dengan tingkat kepercayaan 95\% atau $\alpha=0,005$ didapatkan $\rho$ Value $<\alpha$ tidak terdapat hubungan antara pengetahuan orang tua dengan minat imunisasi Measles Rubella (MR) di Kelurahan Bukit Wolio Indah Kota Baubau.

Secara garis besar domain tingkat pengetahuan (kognitif) mempunyai enam tingkatan, meliputi: mengetahui, memahami, 
menggunakan, menguraikan, menyimpulkan dan mengevaluasi. Ciri pokok dalam taraf pengetahuan adalah ingatan tentang sesuatu yang diketahuinya baik melalui pengalaman, belajar, ataupun informasi yang diterima dari orang lain. Pengetahuan merupakan hasil dan ini terjadi setelah orang melakukan penginderaan terhadap suatu objek tertentu (Green dalam Notoatmodjo,2012).

Penelitian ini sejalan dengan penelitian yang dilakukan oleh (Habibaturrahmi, 2014) dimana hasil penelitian terdapat hubungan yang bermakna antara pengetahuan $(p=0,004)$, ibu terhadap imunisasi $(\mathrm{p}<0,05)$. Kesimpulan penelitian ini menunjukkan pengetahuan, secara signifikan berpengaruh terhadap pemberian imunisasi di Posyandu Puskesmas Jaya Baru Banda Aceh.

Hasil penelitian ini juga sejalan dengan hasil penelitian yang dilakukan oleh (Aprilia et al., 2019) di Puskesmas Taman Bacaan Palembang tahun 2019 bahwa ada hubungan penegetahuan ibu dengan pemberian imunisasi measles rubella p value 0.006 .

\section{Hubungan Antara Sikap dengan Minat Imunisasi Measles Rubella (MR)}

Hasil penelitian menunjukkan bahwa responden yang memiliki sikap positif terdiri dari $60(85,7 \%)$ tetapi 36 responden $(51,4 \%)$ tidak minat imunisasi Measles Rubella (MR) karena mereka takut salah mengambil sikap, tidak yakinnya mereka bahwa demam setelah imunisasi Measles Rubella (MR) itu adalah hal yang wajar dan mereka juga tidak mencari tahu manfaat dari imunisasi Measles Rubella (MR). Akan tetapi responden yang memiliki sikap positif $60(85,7 \%)$ dan minat imunisasi Measles Rubella $(M R)$ terdiri dari 24 responden $(34,3 \%)$ karena mereka mendapatkan informasi tentang pentingnya imunisasi Measles Rubella (MR) bagi bayi.

Responden yang memiliki sikap negatif terdiri dari 10 responden $(14,3 \%)$ dan terdapat 9 responden $(12,9 \%)$ minat imunisasi Measles Rubella (MR) karena rumah mereka dekat dengan kegiatan posyandu yang dilakukan sehingga pada saat posyandu diadakan petugas kesehatan mengajak ibu-ibu tersebut untuk datang dan bayi mereka diimunisasi Measles Rubella (MR), selanjutnya ibu yang memiliki sikap negatif dan tidak minat imunisasi Measles Rubella (MR) terdiri dari 1 responden $(1,4 \%)$ karena mereka beranggapan tanpa imunisasi
Measles Rubella (MR) pun bayi mereka akan tetap sehat.

Hasil analisis penelitian disimpulkan bahwa pada variabel sikap Hasil uji statistik dengan tingkat kepercayaan $95 \%$ atau $\alpha=0,004$ didapatkan $\rho$ value $<\alpha$ terdapat hubungan antara sikap orang tua dengan minat imunisasi Measles Rubella (MR) di Kelurahan Bukit Wolio Indah Kota Baubau.

Azwar (2007) dalam (Soekidjo Notoadmodjo, 2012) menyatakan sikap merupakan kesiapan untuk bereaksi terhadap suatu objek dengan cara tertentu, bentuk reaksinya dengan positif dan negatif, sikap meliputi rasa suka dan tidak suka, mendekati dan menghindari situasi, benda, orang, kelompok, dan kebijaksanaan sosial.

Berdasarkan hasil penelitian (Fantaria, 2014) dimana hasil penelitian Terdapat hubungan yang bermakna antara sikap, ibu terhadap imunisasi $(\mathrm{p}<0,05)$ di Wilayah Kecamatan Darussalam Aceh Besar Tahun 2014.

Hasil penelitiani ini juga sejalan dengan penelitian yang dilakukan oleh (Emilya et al., 2017) di Kelurahan Lambung Bukit Tahun 2014 menunjukkan bahwa ada hubungan yang bermakna antara sikap dengan pemberian imunisasi dasar lengkap dengan nilai $\mathrm{p}$ value 0,0003 .

\section{Hubungan Antara Dukungan Keluarga dengan Minat Imunisasi Measles Rubella (MR)}

Hasil penelitian menunjukkan bahwa responden yang didukung oleh keluarga terdiri dari 27 (38,6\%) dan tidak minat imunisasi Measles Rubella (MR) sebanyak 17 responden $(24,3 \%)$ karena menganggap bahwa imunisasi Measles Rubella (MR) itu tidak begitu penting, dan berkata tanpa imunisasi pun anak tetap sehat, selanjutnya responden yang didukung oleh keluarga terdapat $10(14,3 \%)$ responden minat imunisasi Measles Rubella (MR) pada bayi karena menganggap bahwa imunisasi Measles Rubella (MR) itu penting, dan suami ataupun keluarga lainnya mendukung ibu tentang imunisasi Measles Rubella (MR).

Responden yang tidak didukung oleh keluarga 43 responden $(61,4 \%)$ dan minat imunisasi Measles Rubella (MR) pada bayi 23 responden $(32,9 \%)$ karena ibu merasa perlu untuk mengindahkan anjuran tenaga kesehatan, sehingga tanpa dukungan keluarga ibupun 
berminat untuk imunisasi Measles Rubella $(M R)$ pada bayinya, selanjutnya responden yang tidak didukung oleh keluarga dan tidak minat imunisasi Measles Rubella (MR) pada bayi terdiri dari 20 responden $(28,6 \%)$ hal ini karena ibu tidak mendapatkan dukungan keluarga tentang imunisasi Measles Rubella (MR) disebabkan tidak yakinnya mereka atas kehalalan vaksin MR.

Hasil penelitian disimpulkan bahwa pada variabel dukungan keluarga Hasil uji statistik dengan tingkat kepercayaan $95 \%$ atau $\alpha$ $=0,273$ didapatkan $\rho_{\text {Value }}<\alpha$ tidak terdapat hubungan antara dukungan keluarga dengan minat imunisasi Measles Rubella (MR) di Kelurahan Bukit Wolio Indah Kota Baubau.

Perlunya beberapa himbauan ataupun informasi tentang imunisasi MR yang dapat mengarahkan individu yang khususnya seorang ibu ataupun anggota keluarga lainnya agar munculnya dukungan keluarga terhadap ibu untuk melaksanakan imunisasi MR dan membentuk opini keluarga maupun ibu yang baik terhadap suatu hal, khususnya dalam penelitian ini yaitu tentang dukungan keluarga dengan minat imunisasi MR dan juga dapat didukung dengan adanya promosi kesehatan yang dilakukan oleh petugas kesehatan yang memiliki pengetahuan yang sangat cukup tentang imunisasi MR. Sehingga, besar kemungkinan untuk terciptanya opini, percaya akan kehalalannya, nyaman, aman, dan perilaku berminat imunisas MR, serta diperlukannya komunikasi yang persuasif melalui promosi kesehatan maupun pendidikan kesehatan sehingga responden lebih memahami mengenai informasi yang mereka dapatkan untuk meningkatkan kesadaran mengenai pentingnya imunisasi MR pada bayi.

Keluarga adalah salah satu kelompok atau kumpulan manusia yang hidup bersama sebagai satu kesatuan atau unit masyarakat terkecil dan biasanya selalu ada hubungan darah, ikatan perkawinan atau ikatan lainnya, tinggal bersama dalam satu rumah yang dipimpin oleh seorang kepala keluarga.

Hasil penelitian diatas didukung oleh penelitian (Ilham, 2017). Penelitian ini menyimpulkan bahwa nilai signifikansi lebih besar dari $0,05(0.274>0.05)$ maka dapat ditarik kesimpulan bahwa $\mathrm{HO}$ diterima dan $\mathrm{Ha}$ ditolak, artinya tidak terdapat hubungan dukungan keluarga dengan kepatuhan ibu melaksanakan imunisasi dasar lengkap pada bayi di Wilayah Kerja Puskesmas Pemangkat Kabupaten Sambas.

Hasil penelitian ini juga sejalan dengan hasil penelitian yang dilakukan oleh (Aprilia et al., 2019) di Puskesmas Taman Bacaan Palembang tahun 2019 bahwa ada hubungan dukungan keluarga dengan pemberian imunisasi measles rubella $\mathrm{p}$ value 0.000 .

\section{KESIMPULAN DAN SARAN}

Berdasarkan hasil penelitian, maka dapat disimpulkan bahwa ada hubungan pengetahuan dan sikap dengan minat imunisasi Measles Rubella (MR) di Kelurahan Bukit Wolio Indah Kota Baubau. Tidak ada hubungan dukungan keluarga dengan minat imunisasi Measles Rubella (MR) di Kelurahan Bukit Wolio Indah Kota Baubau.

Berdasarkan hasil dan kesimpulan penelitian, maka dapat disarankan untuk meningkatkan pengetahuan orang tua balita (ayah dan ibu) dengan promosi kesehatan tentang bahaya penyakit campak rubella bagi balita, fatwa MUI tentang status vaksin MR, dan manfaat imunisasi MR bagi balita, serta menambah sasaran promosi kesehatan terkait imunisasi MR, serta melakukan kerjasama lintas sektor seperti dengan tokoh masyarakat, untuk meningkatkan minat imunisasi MR di Kelurahan Bukit Wolio Indah Kota Baubau.

\section{DAFTAR PUSTAKA}

American Red Cross CDC; UNICEF; UNF \& WHO. (2017). Measles and Rubella Global Update. Measles and Rubella Global Update.

Aprilia, R., Satya, S., \& Minarti, M. (2019). Hubungan Pengetahuan dan Dukungan Keluarga dengan Pemberian Imunisasi Neasles Rubella. Jurnal 'Aisyiyah Medika, 4(2). https://doi.org/10.36729/ jam.v4i2.222

Baubau, D. K. (2019). Profil Dinas Kesehatan Kota Baubau Tahun 2018. Dinkes Kota Baubau.

Ditjen P2P. K. R. (2016). Petunjuk Teknis Kampanye Imunisasi Measles Rubella (MR). In Pedoman Imunisasi MR. Kemenkes RI.

Emilya, S., Lestari, Y., \& Asterina, A. (2017). Hubungan Pengetahuan dan Sikap Ibu Balita terhadap Tindakan Imunisasi Dasar Lengkap di Kelurahan Lambung Bukit Kota Padang Tahun 2014. Jurnal 
Kesehatan Andalas, 6(2), 386. https://doi.org/10.25077/jka.v6i2.709

Fantaria. (2014). Hubungan Pengetahuan Ibu Tentang Imunisasi Dasar dengan Kelengkapan Imunisasi Dasar Pada Balita di Wilayah Kecamatan Darussalam Aceh Besar Tahun 2014. Unsyiah.

Habibaturrahmi. (2014). Hubungan Pengetahuan, Sikap dan Pekerjaan Ibu Terhadap Pemberian Imunisasi Hepatitis B0 di Posyandu Puskesmas Jaya Baru Banda Aceh. Unsyiah.

Ilham. (2017). Hubungan Dukungan Keluarga Dengan Kepatuhan Ibu Melaksanakan Imunisasi Dasar Lengkap Pada Bayi di Wilayah Kerja Puskesmas Pemangkat Kabupaten Sambas. Universitas Tanjungpura.
Kemenkes RI. (2017). Petunjuk Teknis Kampanye dan Introduksi Imunisasi Maesles Rubella (MR). Direktorat Jenderal Pencegahan dan Pengendalian Penyakit Kementerian Kesehatan Republik Indonesia.

Puskesmas Bukit Wolio Indah. (2019). Profil Kesehatan Puskesmas Bukit Wolio Indah. Puskesmas BWI.

Soekidjo Notoadmodjo. (2012). Promosi kesehatan dan Perilaku Kesehatan. Rineka Cipta.

Tenggara, D. P. S. (2018). 2018. Profil Kesehatan Provinsi Sulawesi Tenggara Tahun 2017. Dinkes Provinsi Sulawesi Tenggara. 